\title{
Excretion Product of Shigella dysenteriae (SdyEP) Induced Cell Death in Early Larval Stage of Zebrafish (Danio rerio): Acridine Orange and Ethidium Bromide (AO/EB) in vivo Staining
}

\author{
Producto de Excreción de Shigella Dysenteriae (PESdy) Induce Muerte Celular en Larvas de Pez \\ Cebra (Danio rerio): Marcaje in vivo con Naranja de Acridina y Bromuro de Etidio (NA/BE)
}

Alvarez, M.*; Urbina, G.* \& Perdomo, L.*

ALVAREZ, M.; URBINA, G. \& PERDOMO, L. Excretion product of Shigella dysenteriae (SdyEP) induced cell death in early larval stage of zebrafish (Danio rerio): Acridine orange and ethidium bromide (AO/EB) in vivo staining. Int. J. Morphol., 32(1):84-89, 2014.

SUMMARY: In the field of studies of acute toxicity induced by bacterial agents, Shiga toxins have been relevant due to the severity of the extra-intestinal diseases they cause. Numerous studies have shown that Shiga toxin induced apoptosis in different cell types; however, this important process has been little studied in vivo experimental models. In this study, the effects of excretion products of Shigella dysenteriae, in which Shiga toxin is present, were investigated on early larval stages of Zebrafish, an animal model with many advantages over other in vivo experimental models traditionally used. Both the collection of eggs and larvae of Zebrafish, and the product from excretion from Shigella dysenteriae (SdyEP) were performed according to laboratory standards. Also, toxicity bioassay, larvae treatment with pure and diluted solution, $10-^{1}, 10-^{2}, 10-^{3}, 10-^{4}$ and $10-^{5}$, v/v SdyEP and cell death in vivo using Acridine Orange (AO) and Ethidium Bromide (EB) were applied. The excretion product of Shigella dysenteriae (SdyEP) effect was expressed in terms of larval mortality and dependent dilution rather than incubation time. The larval population surviving treatment with Shigella excretion product presents severe morphological effects. The larval population generally presents notable severe morphological damage, the necrosis state is represented by the opacity of the larvae after being treated for $24 \mathrm{~h}$ (b) compared to control. Other changes associated with larval anatomy were also observed; particularly the caudal end curvature was significant into $10 \%$. The use of AO/EB revealed a distribution pattern from fluorescence into green and orange in surviving larvae SdyEP poisoning, there was a large population of dead cells around the anal and caudal region as evidenced by the presence of orange nuclei in greater numbers as controls in the larvae. The results support the application of coloring AO/EB in Zebrafish experimental models for the evaluation of the toxic action of new molecules and new products with therapeutic potential.

KEY WORDS: Zebrafish (Danio rerio); Shigella dysenteriae; Apoptosis; Acridine Orange; Ethidium Bromide.

\section{INTRODUCTION}

In the field of studies of bacterial toxicity, acute toxicity induced by bacterial agents, particularly bacteria of the genus Shigella sp with Shigella dysenteriae at the top, has been relevant since the Shigella dysenteriae has been highly recognized for its production of one of the major virulence factors for humans such as Shiga toxin (Stxs). Shiga toxins are a family of genetically and functionally related cytotoxic proteins expressed by the enteric pathogens Shigella dysenteriae serotype 1 and certain serotypes of Escherichia coli (Lee et al., 2010). Recently, numerous studies have shown that Shiga toxins induce apoptosis through different mechanisms in different cell types including human epithelial cells, endothelial cells and neurons (Tesh, 2010).

The use of human of renal cortical epithelial cells and a renal carcinoma cell line to investigate the cytotoxic effects of Stxs has shown the Induction of apoptosis in both cell types as evidenced by nuclear fragmentation, DNA laddering, and the presence of terminal deoxynucleotidyltransferase-mediated dUTP-biotin nick end labelling (TUNEL)-positive cells (Lentz et al., 2011). Stxq1-mediated apoptosis of monocytic THP-1 cells involved a novel pathway using components of both the intrinsic and extrinsic 
pathways of apoptosis (Lee et al., 2005). In the case of the excretion product of Shigella dysenteriae $(S d y E P)$ as inducer of apoptosis, this process has been highlighted by the description of morphological signals, indicative of cell death after incubation reported in in vivo and in vitro lower limb skeletal muscle tissue of chicken embryo treated with $S d y E P$ (Alvarez et al., 2007).

In order to make use of another easily accessible toxicological model which allows a simple determination of cellular death, the present work uses the early larval stage of Zebrafish experimental model and conventional staining Acridine Orange (AO), in combination with Ethidium Bromide (EB), (AO/EB) (Tucker \& Lardelli, 2007). For this study, the toxic damage induced by $S d y E P$ was reevaluated. This study was carried out in a Zebrafish larvae experimental model since in recent years; it has been described as an excellent in vivo model for the study of apoptosis. The Zebrafish, adult and embryonic, has great advantages for acute toxicity tests and has the versatility required to examine aspects of genetics, developmental biology, and cellular and tissue effects caused by toxic agents (Parng, 2005). The estimation of the level of apoptosis in embryonic Zebrafish has been commonly implemented through staining with vital dyes such as AO, a dye to characterize cell death via a process of relocation of fluorescence in cells in culture (Alvarez et al., 2011). Its application in combination with EB has been selected for its simplicity, speed and accuracy (Renvoizé et al., 1998).

\section{MATERIAL AND METHOD}

\begin{abstract}
Shigella dysenteriae Excretion Product of $S d y E P$. Cultures of strain Shigella dysenteriae Type I at a concentration of $1 \times 108$ cells $/ \mathrm{ml}$, incubated in medium brain-heart infusion (BIH-Difco) at $37^{\circ} \mathrm{C}$ for $48 \mathrm{~h}$ allowed to obtain the supernatant or $S d y E P$ after centrifugation at $6000 \mathrm{rpm}$ at $4^{\circ} \mathrm{C}$ for $30 \mathrm{~min}$ and filtered on Millipore membranes of 22 $\mathrm{mm}$. The $S d y E P$ obtained was placed in aliquots and frozen until subsequent application in various tests. The cytotoxicity assay on Vero cells was used as positive control for the presence of Shiga toxin in the obtained $S d y E P$.
\end{abstract}

Larval toxicity. The Zebrafish colony was established in the laboratory, in an environmental growth or glass aquarium, provided with internal filter and aerator activated carbon for water oxygenation. The population of animals was fed three times a day with food chips (Kantal S.A) for fish. Adult fish were kept on $16 \mathrm{~h}$ light and 10h dark cycles. Embryos were obtained by photo-induced spawning over green plants and were cultured at $28^{\circ} \mathrm{C}$ in fish tank water. Early larva post- fertilization Zebrafish were maintained according to Kimmel et al. (1995). The dechorionted embryos, larvae of $5 \mathrm{dpf}$, were then incubated in 24-well plates, 10 larvae per well for each dilution of $S d y E P$. Embryos were dechorionted using forceps under a stereomicroscope. The excretion product of Shigella dysenteriae ( $S d y E P$ ) was used P (pure) and diluted in fish tank water at concentrations of $10^{-1}, 10^{-2}, 10^{-3}, 10^{-4}$ and $10^{-5} \mathrm{v} / \mathrm{v}$. The volume of fish tank water was $200 \mu \mathrm{l} / \mathrm{well}$. The effect of each dilution placed in wells of $200 \mu \mathrm{l}$, with 10 larvae / well, was measured at 1, 24 and 36 hours from incubation. After $24 \mathrm{~h}$ of treatment the mortality as well as the morphologic changes was assessed. After their respective times, we determined the percentage of larval death in each dilution. This percentage was plotted versus time. Groups from 10 larvae/well in aquarium water were used as controls. Stereoscopic microscope images were taken for obtaining registration expressed morphological effects on larval anatomy as compared to controls.

Cell death: Acridine Orange (AO) and Ethidium Bromide (EB). The surviving larvae of $6 \mathrm{dpf}$ and controls were transferred to Acridine Orange (AO) / Ethidium Bromide (EB) solution; both at $0.5 \mathrm{mg} / \mathrm{ml}$ for 30 minutes. The AO pervades all living cells and provides a green color to the core, unlike BE, that is only incorporated into the cell when this has lost membrane integrity, giving a red color to the nucleus. After labelling time, the larvae were observed under the fluorescence microscope, BX71 OLYMPUD. Through the program ImageJ, the analysis of the areas from green fluorescence was performed, highlighting areas of tissue with living cells and tissue areas with permeable cell $\mathrm{BE}$. The use of the image analysis program ImageJ allowed to estimate the fluorescence intensity in different regions of the larvae, under control and treated conditions.

\section{RESULTS}

The $S d y E P$ effect was expressed in terms of larval mortality, resulted dependent dilution was used rather than incubation time (Fig. 1). The pure (P) SdyEP and the dilutions $10^{-1}$ and $10^{-2}$ produced $100 \%$ death to larval at 1,24 and 36 hours of incubation. While the dilutions $10^{-3}$ and $10^{-4}$ produced a mortality of $50 \%$ after 36 hours of incubation. The dilution of $10^{-5}$ produced a mortality of $35 \%$ at 36 hours of incubation. With these low dilutions, from 1 to 24 hours, mortality was $0 \%$ similar to the control. The larval population generally presents severe morphological damage (Fig. 2).

Notably, the state from necrosis, represented by the characteristic shown into opacity larvae treated for $24 \mathrm{~h}$ (b) compared to control. Other changes associated with larval 


\section{Shigella dysenteriae excretion product \& zebrafish larvae (Danio rerio)}

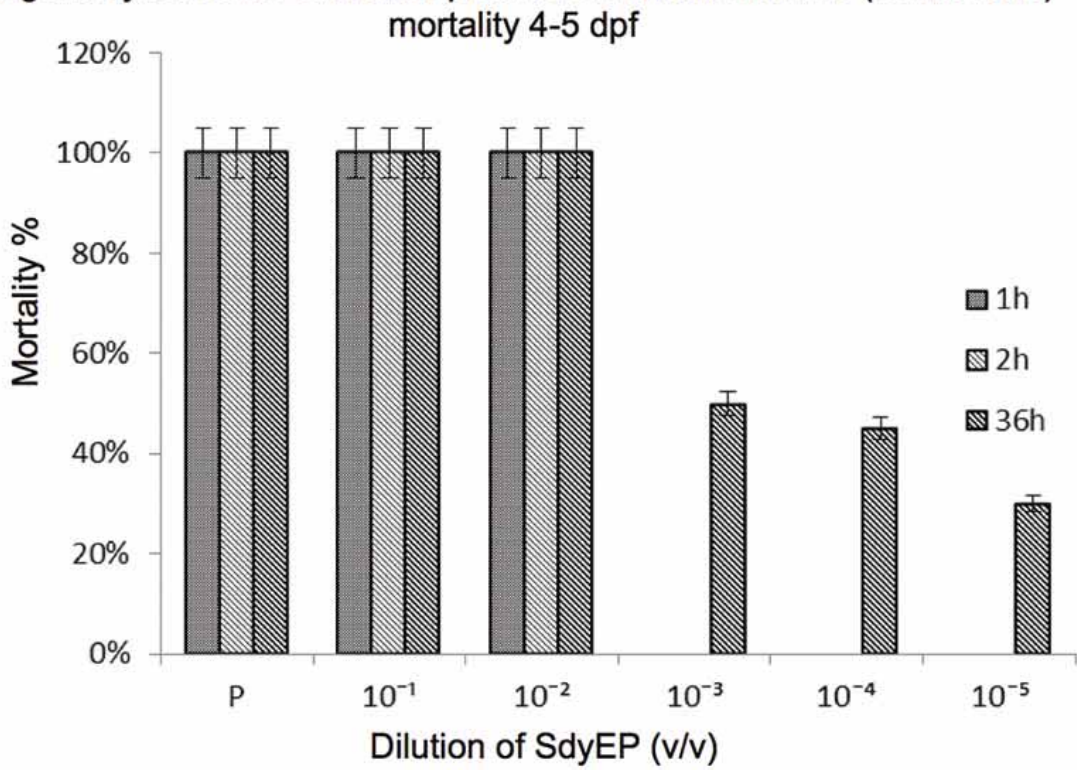

Fig. 1. Mortality percentage of Zebrafish larvae treated with Pure $(\mathrm{P})$ and diluted Shigella dysenteries excretion product $(S d y E P)$ at different incubation times 2 $\mathrm{h}, 24 \mathrm{~h}$ and $36 \mathrm{~h}$. Results reported as mean \pm SE for two replicates with 10 larvae/ replicate. Significant differences are shown by asterisk. 50\% survival at low dissolution was between $10^{-1}$ and $10^{-2}$.

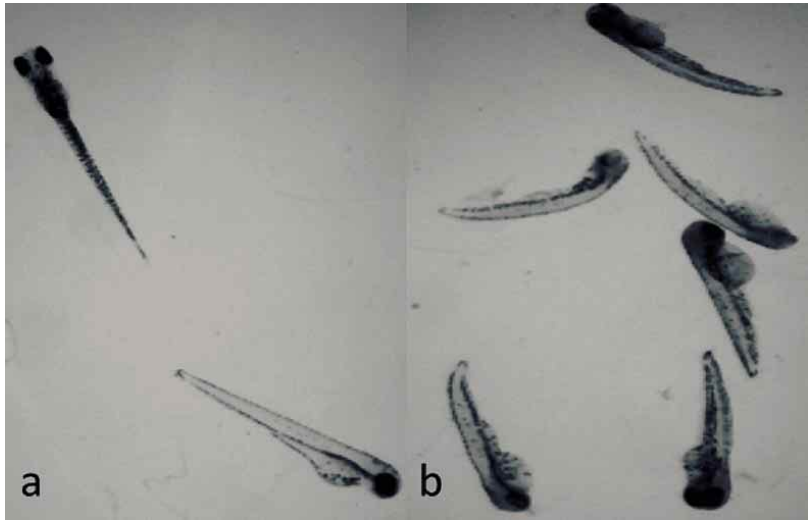

Fig. 2. Shigella dysenteriae excretion product $(S d y E P)$ induced morphological changes in body axis. Representative picture of Shiga effects show dorsal curvature in Zebrafish larvae. Control (a) and experimental groups. Magnification 20X.

anatomy were also observed; particularly the caudal end curvature (arrow) was significant into $10 \%$. The use of AO/ EB revealed a distribution pattern from fluorescence into green and orange (Fig. 3).

In surviving larvae $S d y E P$ poisoning, there was a large population of dead cells around the anal (arrow) and most posterior caudal region (double arrow), as evidenced by the presence of orange nuclei, in greater numbers as control in the larvae. The difference between white cells and red, green and orange fluorescence, respectively was expressed in terms of the area of tissue covered (Fig. 4).

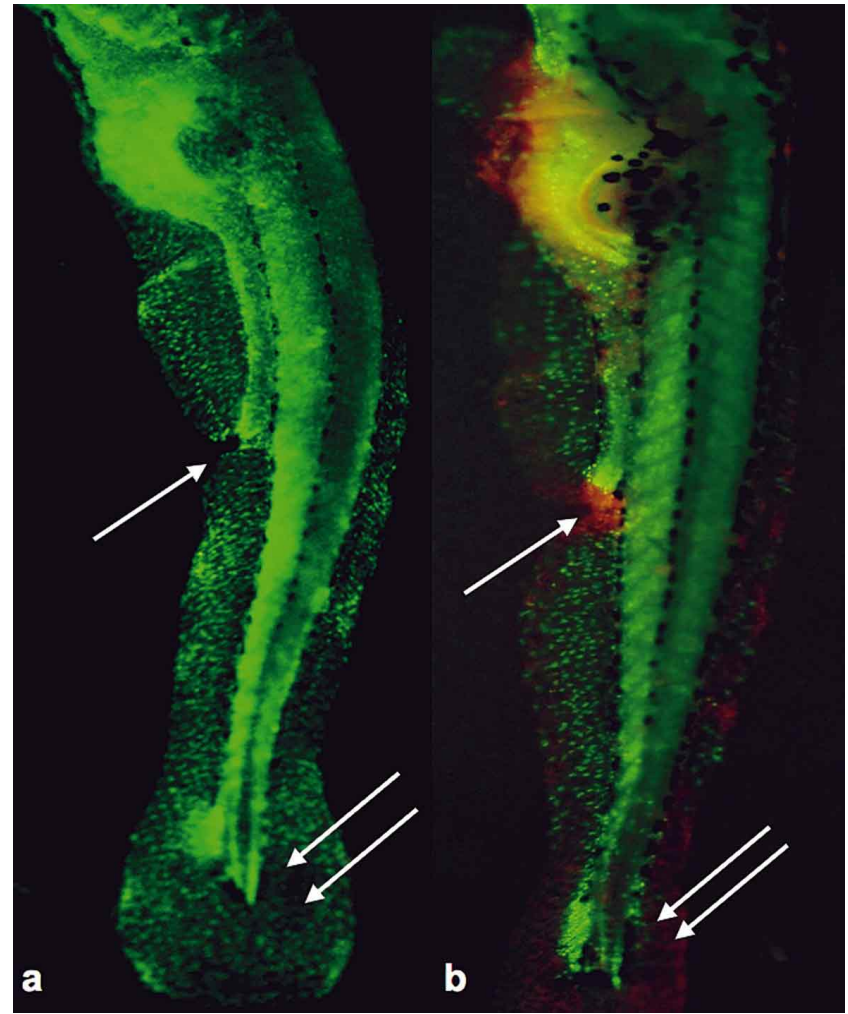

Fig. 3. Zebrafish larvae: control (Fig. 3a) and larvae surviving to treatment with $S d y E P$ (Fig. 3b). Anal region single arrow: a) control living cells permeable NA, green nuclei, b) dead cells permeable $\mathrm{BE}$, orange colored nuclei. Caudal region double arrow: Pattern of cell death determined AO/EB was higher in the treated larvae. Magnification 40X. 


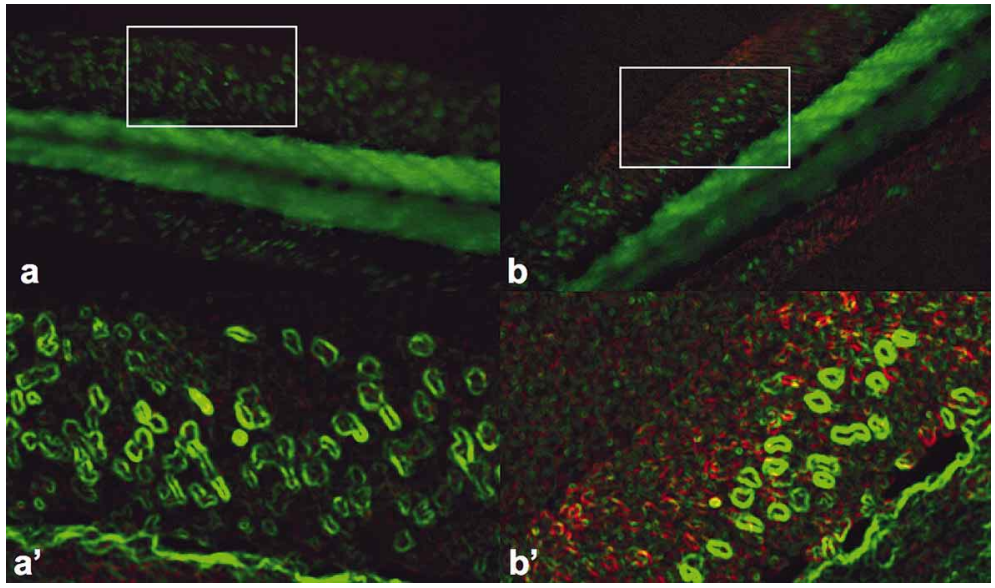

Fig. 4. ImageJ processed 8-bit images. The contents of the highlighted rectangle was processed with a filter variance and analyzed through the density determination RGB (Red, Green, Blue). Control (aa') and $S d y E P$-treated (b-b'). The proportion of orange and green is highlighted.

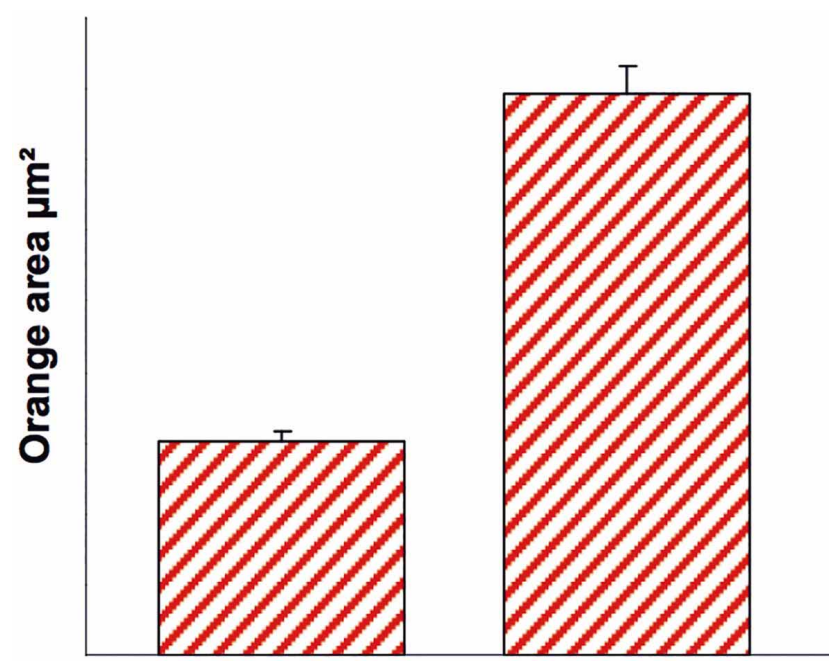

Fig. 5. Bar graph showing the difference between the current area of orange in the control compared with treated $S d y E P$. Processed using Microsoft Excel. $\mathrm{n}=15$ images 8-bit/group.

\section{DISCUSSION}

The results demonstrate the $S d y E P$ toxic action through the registration of a high larval mortality as a result of high concentrations of excretion product, regardless of incubation time, as well as the estimation, semi-quantitative, injury induced cell, as evidenced by staining the combined use of AO/EB. Cellular damage registered, reminds of cell damage found in renal tubular epithelial cells of patients infected with Shiga toxin. These patients show destruction of endothelial cells of small blood vessels and organs that are located outside the gastrointestinal tract, as a direct consequence of the action of Shiga toxin type 1 (Stx1) (Creydt et al., 2005). The $S d y E P$-induced cell damage could therefore be linked to the destruction of endothelial cells of small blood vessels near the anal region of the gastrointestinal tract. The cells of the blood vessels provide a target for the toxic action in a Zebrafish larvae experimental model.

Our results indicated that this cell damage could be linked, in turn, to the induction of cell death mediated by apoptosis in the regions indicated above. In this regard, note that the NA acts by intercalation into the DNA molecule or by electrostatic attraction with the RNA molecule (Ribble et al., 2005; Lopes et al., 2001). When DNA is associated with the Acridine orange, it is spectrally similar to fluorescein, it presented an excitation maximum at $502 \mathrm{~nm}$ and emission at $525 \mathrm{~nm}$, in the green. When associated to RNA derived maximum excitation at $460 \mathrm{~nm}$ in the blue and the maximum emission at $650 \mathrm{~nm}$ in the red. Therefore, the cell populations with emission in the green, in our results, correspond to cells undergoing active division with greater presence of DNA, while cells with orange emission, and correspond to those found in a state of multiplicative rest, with greater presence of RNA and protein. By using the NA, together with the BE, it was possible, in a simple way, to differentiate between living cells and / or cells in early stages of apoptosis or necrosis. From the foregoing, it is evident that the $S d y E P$ led to DNA fragmentation characteristic of apoptosis induction mediated by Shiga toxin (Stx1, STtx2) as shown by other authors (Cherla et al., 2003). In this regard, numerous studies have examined the mechanism of cell death mediated by purified STx. Many cell types have been used, including epithelial cells, endothelial cells, monocytes cells, and amnion cell lines. The Shiga toxin (STx) generally induces a typical characteristic pattern of cell lysis programmed cell death or apoptosis, DNA degradation and the release of cellular contents. This process may facilitate photolytic attack on neighbouring cells, contributing to the toxic effect on the 
whole organism. This would explain the observed effect on necrotic dead larvae, as a result of treatment. Moreover, some signalling mechanisms of programmed cell death induced by Shiga toxin have been described. Some of them demonstrate the requirement for the activation of caspase- 12 .

In mice, Caspase 12 appears to be localized in the endoplasmic reticulum (ER), which when activated generates stored calcium release (Nakagawa et al., 2000). The imbalance in the calcium ion would result in the destabilization of the membranes through changes in cell junctions by decreasing cell-cell communications (Orrenius et al., 1989). It cannot be determined If any of the processes described above are modulating the action induced by the toxic excretion product Shigella dysenteriae ( $S d y E P$ ) on epithelial cells in the Zebrafish larvae model studied. However, there remains the possibility to further deepen investigate the possible mechanisms related to such action.

\section{ACKNOWLEDGMENTS}

By Alberto Alfonzo, Degree in Translation, for the correctness of language. At the Consejo de Desarrollo Científico y Humanístico (CDCH) PG: No.09-8169-2011/1.

ALVAREZ, M.; URBINA, G. \& PERDOMO, L. Producto de excreción de Shigella dysenteriae (PESdy) induce muerte celular en larvas de pez cebra (Danio rerio): Marcaje in vivo con Naranja de Acridina y Bromuro de Etidio (NA/BE). Int. J. Morphol., 32(1):84-89, 2014.

RESUMEN: En el campo de los estudios de toxicidad aguda inducida por agentes bacterianos, las toxinas Shiga resultan relevantes debido a la severidad de las enfermedades extra-intestinales que causan. Numerosos estudios han demostrado que la toxina Shiga induce la apoptosis en diferentes tipos de células, sin embargo, este importante proceso ha sido poco estudiado en modelos experimentales in vivo. En este estudio, fueron evaluados los efectos del productos de excreción de Shigella dysenteriae (PESdy), sobre estadios larvarios de pez cebra (Danio rerio), un modelo animal con muchas ventajas sobre otros modelos experimentales in vivo utilizados tradicionalmente. Tanto la recolección de los huevos y larvas de pez cebra, así como la obtención del producto de la excreción, se realizaron de acuerdo a los estándares de laboratorio. Poblaciones larvarias, fueron tratadas con distintas soluciones; pura y diluidas, $10^{1}$, $10^{-2}, 10^{-3}, 10^{-4}$ y $10^{-5}$, v/v de PESdy. La muerte celular in vivo, usando naranja de acridina (NA) y bromuro de etidio (BE) fue evaluada. El efecto del $S d y E P$, se expresó como dependiente de la concentracion y del tiempo de exposición. La población de larvas sobrevivientes, presentaron curvatura troncal en un $10 \%$, en relación a los controles. La necrosis se puso en evidencia a través de la opacidad de las larvas después de 24 h. El uso de NA/BE reveló un patrón de distribución de la fluorescencia en verde y naranja en larvas sobrevivientes al tratamiento. Una granpoblación de células muertas, alrededor de la región anal y caudal, se ponen en evidencia por la presencia de núcleos de naranja en mayor número que en los controles. Los resultados apoyan la aplicación de la coloración NA/BE en modelo experimental de pez cebra, para la evaluación de la acción tóxica de nuevas moléculas y nuevos productos de excreción bacterial con potencial terapéutico.

PALABRAS ClAVE: Pez cebra (Danio rerio); Shigella dysenteriae; Apoptosis; Naranja de Acridina; Bromuro de Etidio.

\section{REFERENCES}

Alvarez, M.; Urbina, G.; Müller, C. \& Perdomo, L. Excretion Products of Shigella dysenteriae and Apoptotic Cell Death on Chick Embryo Muscle Tissue. Int. J. Morphol., 25(3):615-20, 2007.

Alvarez, M.; Villanueva, A.; Acedo, P.; Cañete, M. \& Stockert, J. C. Cell death causes relocalization of photosensitizing fluorescent probes. Acta Histochem., 113(3):363-8, 2011.

Cherla, R. P.; Lee, S. Y. \& Tesh, V. L. Shiga toxins and apoptosis. FEMS Microbiol. Lett., 228(2):159-66, 2003.

Creydt, V. P.; Nuñez, P.; Zotta, E. \& Ibarra, C. Cytotoxic effect of Shiga toxin type 2 and its B subunit on human renal tubular epithelial cells in culture. Medicina ( $B$. Aires), 65(2):147-50, 2005.

Kimmel, C. B.; Ballard, W. W.; Kimmel, S. R.; Ullmann, B. \& Schilling, T. F. Stages of embryonic development of the Zebrafish. Dev. Dyn., 203(3):253-310, 1995.

Lee, M. S.; Cherla, R. P. \& Tesh, V. L. Shiga toxins: intracellular trafficking to the ER leading to activation of host cell stress responses. Toxins (Basel), 2(6):1515-35, 2010.

Lee, S. Y.; Cherla, R. P.; Caliskan, I. \& Tesh, V. L. Shiga toxin 1 
ALVAREZ, M.; URBINA, G. \& PERDOMO, L. Excretion product of Shigella dysenteriae (SdyEP) induced cell death in early larval stage of zebrafish (Danio rerio): Acridine orange and ethidium bromide (AO/EB) in vivo staining. Int. J. Morphol., 32(1):84-89, 2014

induces apoptosis in the human myelogenous leukaemia cell line THP-1 by a caspase-8-dependent, tumor necrosis factor receptor-independent mechanism. Infect. Immun., 7(8):511526,2005

Lentz, E. K.; Leyva-Illades, D.; Lee, M. S.; Cherla, R. P. \& Tesh, V. L. Differential response of the human renal proximal tubular epithelial cell line HK-2 to Shiga toxin types 1 and 2. Infect. Immun., 79(9):3527-40, 2011.

Lopes, E. C.; Garcia, M. G.; Vellón, L.; Alvarez, E. \& Hajos, S. Correlation between Decreased apoptosis and multidrug resistance (MDR) in murine leukemic T cell lines. Leuk. Lymphoma, 42(4):775-87, 2001.

Nakagawa, T.; Zhu, H.; Morishima, N.; Li, E.; Xu, J.; Yankner, B. A. \& Yuan, J. Caspase 12 mediates endoplasmic reticulum specific apoptosis and cytotoxicity by amyloidal-b. Nature, 403(6765):98-103, 2000

Orrenius, S.; McConkey, D. J.; Bellomo, G. \& Nicotera, P. Role of $\mathrm{Ca} 2+$ in toxic cell killing. Trends Pharmacol. Sci., 10(7):2815,1989 .

Parng, C. In vivo Zebrafish Assays for toxicity testing. Curr. Opin. Drug Discov. Devel., 8(1):100-6, 2005.

Renvoizé, C.; Biola, A.; Pallardy, M. \& Breard. J. Apoptosis: identification of dying cells. Cell Biol. Toxicol., 14(2):111-20, 1998.

Ribble, D.; Goldstein, N. B.; Norris, D. A. \& Shellman, Y. G. A simple technique for Quantifying apoptosis in 96-well plates. BMC Biotechnol., 5:12, 2005.

Tesh, V. L. Induction of apoptosis by Shiga toxins. Future Microbiol., 5(3):431-53, 2010.

Tucker, B. \& Lardelli, M. A rapid apoptosis assay measuring relative Acridine orange fluorescence in Zebrafish embryos. Zebrafish, 4(2):113-6, 2007.

\author{
Correspondence to: \\ Dr. Marco Alvarez \\ Sección de Microscopia \\ Instituto Anatómico "José Izquierdo" \\ Facultad de Medicina \\ Universidad Central de Venezuela \\ Caracas \\ VENEZUELA
}

\section{Email: alvarezmenator@gmail.com marco.alvarez@ucv.ve}

Received: 25-03-2013

Accepted: 13-12-2013 